\title{
Efektivitas Biolarvasida Serai Wangi (Cymbopogon nardus) dengan Daun Cengkeh (Syzygium aromaticum L.) Terhadap Larva Aedes aegypti
}

\author{
Christina L. Salaki ${ }^{1 *}$, Herlina Wungouw ${ }^{2)}$, Henny V. Makal ${ }^{1)}$ \\ 1)Fakultas Pertanian Universitas Sam Ratulangi Manado, Indonesia \\ ${ }^{2)}$ Fakultas Kedokteran Universitas Sam Ratulangi Manado, Indonesia \\ Jln.Kampus Unsrat Bahu Manado (95115) \\ *) Corresponding author:christinasalaki@ymail.com
}

\begin{abstract}
ABSTRAK
Penelitian ini menguji efektivitas kombinasi biolarvasida minyak atsiri serai wangi (Cymbopogon nardus) dengan daun cengkeh (Syzygium aromaticum l.) Terhadap larva nyamuk Ae. aegypti. Penelitian ini bertujuan untuk: (a) menganalisis pengaruh pemberian kombinasi biolarvasida minyak atsiri serai wangi dan daun cengkeh terhadap perkembangan larva Ae. aegypti, (b) menganalisis uji daya bunuh kombinasi biolarvasida serai wangi (sw) dan daun cengkeh (dc) terhadap larva Ae. aegypti, (c) menganalisis uji patogenisitas dari kombinasi biolarvasida serai wangi dan daun cengkeh terhadap larva Ae. aegypti. Uji kombinasi biolarvasida ini dilakukan terhadap larva nyamuk Ae. aegypti instar III dengan perlakuan variasi kombinasi konsentrasi "SW $2 \%(\mathrm{P})$ ", " SW 0,75\%" + "DC1,25\% (P1)", "SW 1\%" + "DC 1\% (P2)", "SW 1,25\%" + "DC $0,75 \%(\mathrm{P} 3)$ ", "DC $2 \%(\mathrm{P} 4)$ ". dan Kontrol air (P-). Themepos (P+). Parameter yang diamati meliputi gejala, persentase mortalitas dan waktu kematian. Mortalitas larva diamati pada jam ke-6,12,18,24 setelah aplikasi. Perbedaan proporsi mortalitas antar tingkat konsentrasi dengan control diuji dengan metode chi-kuadrat sedangkan 1T50 dengan analisis probit. Hasil penelitian menunjukkan masing-masing kombinasi bahan uji (P,P1,P2,P3 dan P4) tidak memiliki perbedaan pengaruh yang sginifikan sebagai biolarvasida dengan taraf signifikansi sebesar 0,05 .. Kesimpulan hasil penelitian ini bahwa kelima konsentrasi bahan uji tersebut tidak memberikan perbedaan pengaruh yang signifikan sebagai biolarvasida. Hal ini menunjukkan bahwa minyak atsiri serai wangi dan daun cengkeh baik diaplikasi secara tunggal maupun dikombinasi memiliki efektifitas larvasida yang sama dengan temephos dalam membunuh larva nyamuk Ae. aegypti. Waktu kematian (LT50) ekstrak serai wangi 12,72 jam, daun cengkeh 6,71 jam dan kombinasi 6,38 jam.
\end{abstract}

Kata kunci: Biolarvasida; efektifitas; konsentrasi; patogenisitas

\section{The Effectiveness of Biolarvacide Essential Oil of Vitronella (Cymbopogon nardus) with Clove Leaves (Syzygium aromaticum.L.) on Ae. aegypti Mosquito Larvae}

\begin{abstract}
This study tested the effectiveness of the biolarvicide combination of citronella essential oil (cymbopogon nardus) and clove leaf (syzygium aromaticum L.) against the larvae of Ae. aegypti. This study aims to: (a) analyze the effect of giving a combination of biolarvicides of citronella essential oil and clove leaves on the development of Ae. aegypti, (b) analyzing the killing power of the combination of citronella (sw) and clove leaf (dc) biolarvicides against Ae. aegypti, (c) analyzing the pathogenicity test of the combination of citronella and clove leaf biolarvicides against the larvae of Ae. Agypti. This biolarvicide combination test was carried out on the larvae of Ae. aegypti instar iii with treatment variations in the concentration combination "SW 2\% (P)", "SW $0.75 \% "$ + "DC1.25\% (P1)", "SW 1\%" + "DC 1\% (P2)", "SW 1.25\%" + "DC 0.75\% (P3)", "DC $2 \%(\mathrm{P} 4)$ ". and Water control (P-). Themepos (P+). Parameters observed included symptoms of mortality percentage and time of death. Larval mortality was observed at 6, 12, 18, 24 hours after application. The difference in the proportion of mortality between concentration levels and control was tested by the chi-square method while the $1 \mathrm{t} 50$ method was tested by probit analysis. The results showed that each combination of test materials did not have a significant difference in effect as a biolarvicide with a significance level of 0.05 . The conclusion of this study was that the five
\end{abstract}


concentrations of the test material did not give a significant difference in effect as a biolarvicide. This indicates that the essential oils of citronella and clove leaves, either applied singly or in combination, have the same larvicidal effectiveness as temephos in killing the larvae of Ae. aegypti. Time of death (1t50) citronella extract 12.72 hours, clove leaf 6.71 hours and the combination 6.38 hours.

Keywords: Biolarvicides; effectiveness; concentration; pathogenicity

(Article History: Received 15-08-2021; Accepted 21-09-2021; Published 22-09-2021)

\section{PENDAHULUAN}

Demam Berdarah Dengue (DBD) adalah infeksi yang disebabkan oleh virus dengue. Penularan virus dengue terjadi dari penderita Demam Berdarah Dengue (DBD) melalui gigitan nyamuk yang termasuk sub genus Stegomya yaitu Ae. aegypti dan Aedes albopictus sebagai vektor primer. Penyakit ini merupakan salah satu masalah kesehatan masyarakat di Indonesia yang jumlah penderitanya semakin meningkat dan penyebarannya semakin luas. Penyakit DBD merupakan penyakit menular yang pada umumnya menyerang pada usia anak-anak umur kurang dari 15 tahun dan juga bisa menyerang pada orang dewasa (Irianto, 2014).

Salah satu upaya untuk membasmi nyamuk dapat digunakan dari alam tanpa harus menggunakan insektisida sintetis yang dapat mempengaruhi kesehatan manusia. Untuk mengurangi efek samping dari penggunaan insektisida sintetis maka perlu dicari alternatif lain dengen memanfaatkan insektisida yang ramah lingkunga (Kihampa $e t$ al., 2009; Prasetyowati, 2016). Salah satu pengembangan insektisida alternatif yaitu menggunakan biolarvasida yang berasal dari tanaman penghasil minyak atsiri (Astriani \& Widawati, 2016; Zen \& Non, 2016). Bahan yang berasal dari alam itu menghasilkan bahan anti nyamuk yaitu daun, akar, batang, biji dan bunganya (Nindatu et al., 2011; Herman, 2010; Wulandari et al., 2011). Minyak atsiri atau disebut juga minyak essensial adalah komoditi ekstra alami dari jenis tumbuhan, yang bersifat mudah menguap pada suhu kamar dan memiliki bau seperti tanaman asalnya. Minyak atsiri biasanya tidak berwarna, terutama apabila baru saja diperoleh dari isolasi, tetapi makin lama akan berubah menjadi gelap karena proses oksidasi (Gutierrez, 2013; Lukman et al., 2012; Utomo \& Nana, 2016).

Minyak atsiri dapat mempengaruhi suatu proses dari matabolisme sekunder yang dapat mempengaruhi oviposisi dari betina $A e$. aegypti, repellent, larvasida dan juga dapat merusak telur Ae. aegypti. Selain itu, minyak atsiri mampu menghambat perkembangan serangga (Ahmad \& Ulfiani, 2018; Dominica \& Handayani, 2019; Kim et al., 2012; Susanti \& Boesri, 2012). Efek yang ditimbulkannya adalah dalam bentuk daya tolak dan daya pencegah. Tanaman penghasil minyak atsiri serai wangi dan daun cengkeh merupakan biolarvasida yang aman untuk kesehatan (Adiyasa et al., 2014; Ismuyanto et al., 2013; Maia \& Moore, 2011). Tujuan dari penelitian ini, yaitu: (a) Menganalisis pengaruh pemberian kombinasi biolarvasida minyak atsiri Serai Wangi (SW) dan daun cengkeh (DC) terhadap larva Ae. aegypti, (b) Menganalisis uji daya bunuh kombinasi biolarvasida minyak atsiri Serai Wangi (SW) dan Daun cengkeh (DC) terhadap larva Ae. aegypti, (c) Menganalisis uji patogenisitas kombinasi biolarvasida minyak atsiri Serai Wangi (SW) dan Daun cengkeh (DC) terhadap larva Ae. aegypti.

\section{METODE PENELITIAN}

Penelitian ini dilaksanakan Di
laboratorium Balai Perlindungan dan
Pengujian Mutu Tanaman Pangan dan
Hortikultura Provinsi Sulawesi Utara dan
Laboratorium Hama Fakultas Pertanian
Unsrat pada bulan Maret sampai Juni 2021.
a. Pembuatan Ekstrak serai wangi (SW) dan
daun cengkeh (DC)
$\quad$ Minyak atsiri serai wangi (SW) dan
daun cengkeh (DC) didapatkan dengan proses
destilasi uap (Rusli, 2010). Minyak atsiri
yang diperolah selanjutnya diencerkan untuk
mendapatkan volume yang diinginkan.

b. Pengujian Biolarvasida

Pengujian biolarvasida dilakukan terhadap larva nyamuk Ae. aegypti instar III dengan memasukkan larva kedalam media berisi air, kemudian dilakukan adaptasi selama 1x24 jam. Larva dikelompokkan dalam 7 kelompok (perlakuan) yaitu P, P1,P2,P3 dan $\mathrm{P} 4$ sedangkan 2 perlakuan lainnya sebagai $\mathrm{P}$ 
(+) dan P (-) berisikan 30 ekor. Percobaan dilakukan dengan 4 kali ulangan. Inkubasi dilakukan selama 1 x 24 jam. Kemudian dilakukan pengamatan larva yang mati pada jam ke 6,12,18 dan 24, kemudian dihitung nilai $\mathrm{LT}_{50}$. dengan analisis probit.

\section{HASIL DAN PEMBAHASAN}

Hasil uji biolarvasida pada Tabel 1 terhadap larva Ae.aegyptI menunjukkan bahwa jumlah mortalitas larva nyamuk $A e$. aegypti mencapai $\geq 90 \%$ setiap konsentrasi perlakuan. Hasil uji terhadap kontrol negatif menunjukkan mortalitas larva nyamuk $A e$. aegypti sebesar $0 \%$ sedangkan hasil uji biolarvasida terhadap kontrol positif (Temephos) menunjukkan respon mortalitas $100 \%$ pada jam ke 24 .

Tabel 1. Mortalitas Larva Ae. aegypti Dengan Perlakuan Kombinasi Serai Wangi (SW) dan Daun Cengkeh (DC)

\begin{tabular}{|c|c|c|c|c|}
\hline $\begin{array}{l}\text { Perlaku- } \\
\text { an }\end{array}$ & Mortali & $\begin{array}{r}\text { Larv } \\
\text { ke }\end{array}$ & (\%) pa & jam \\
\hline & 6 & 12 & 18 & 24 \\
\hline$P(-)$ & 0 & 0 & 0 & 0 \\
\hline $\mathrm{P}$ & $23,3^{*}$ & $56, *$ & $66, *$ & $90, *$ \\
\hline P1 & $33, *$ & $60, *$ & 73 , & $93, *$ \\
\hline P2 & $50, *$ & 63 ,* & $80, *$ & $90,{ }^{*}$ \\
\hline P3 & 53 , * & 73 ,* & $86, *$ & $93, *$ \\
\hline P4 & $60, *$ & 80 ,* & $96,7 *$ & $96, *$ \\
\hline $\mathrm{P}(+)$ & $80,0^{*}$ & $100 *$ & $100 *$ & $100 *$ \\
\hline
\end{tabular}

$*)=p<0,05$ uji $X^{2}$ dengan kontrol negatif

Tabel 1 menunjukkan bahwa konsentrasi perlakuan P, P1, P2, P3 dan P4 secara signifikan memiliki kemampuan larvasida di bawah temephos. Sedangkan pada pengamatan jam ke-24 didapatkan hasil yang tidak signifikan dengan temephos untuk masing-masing perlakuan. Dari hasil penelitian ini didapatkan bahwa minyak atsiri Serai wangi dan daun cengkeh dapat dijadikan sebagai biolarvasida. Jumlah Mortalitas larva nyamuk Ae. aegypti berbeda-beda pada tiap perlakuan. Konsentrasi perlakuan $\mathrm{P}(90,0 \%)$, P1 (93,3\%), P2 (90,0\%), P3 (93,3\%) dan P4 $(96,7 \%)$.

Hasil penelitian ini didapatkan bahwa mortalitas larva Ae. aegypti pada pengamatan jam ke-24 memiliki efektifitas larvasida yang sama dengan Temephos. Perbedaan mortalitas larva pada masing-masing perlakuan dipengaruhi oleh jumlah kandungan zat kimia yang terkandung di dalam minyak atsiri (Adrianus et al., 2015; Nerio et al., 2010). Minyak atsiri memiliki kandungan komponen aktif yang disebut Terpenoid atau Terpena. Zat inilah yang mengeluarkan aroma atau bau khas yang terdapat pada banyak tanaman. Senyawa terpena yang terdapat dalam minyak atsiri terdiri dari dua kelompok yaitu monoterpen dan seskuiterpen. Monoterpen dan terpena memiliki efek larvasida yaitu dengan cara mengganggu susunan saraf pada larva serta menghambat pertumbuhan larva dengan cara menghambat daya makan larva (Diaz et al., 2012; Gunawan, 2019; Fadilah et al., 2017).

Selain itu Serai wangi mempunyai metabolit sekunder antara lain saponin, tanin, kuinon, steroid, kumarin dan minyak atsiri. Kandungan minyak atsiri serai wangi yaitu aldehid, isovalerik, sitronellal, geraniol dan sitrat. Metabolit sekunderseperti saponin dan flavonoid yang dihasilkan bersifat toksik terhadap larva nyamuk dengan menurunkan kemampuan mencerna makanan (Ishak, 2019). Zat aktif yang terkandung pada serai wangi berfungsi sebagai senyawa racun yang apabila mengalami kontak dengan sistem pernapasan larva nyamuk akan membuat larva mati (Cania \& Setyaningrum, 2013; Yulvianti et al., 2014). Menurut Nugroho (2011), citronella pada serai wangi bekerja dengan cara menghambat enzim asetilkolinesterase sehingga terjadi keracunan akut seperti kejang, gangguan SSP (Sistem Saraf Pusat), dan kelumpuhan pernafasan sebagai akibat dari penimbunan asetilkolin yang berujung mengakibatkan kematian pada serangga.

Kandungan zat kimia terbesar dalam minyak atsiri daun cengkeh adalah eugenol $(80,5 \%)$ (Amban \& Suena, 2010; Fayemiwo et al., 2014). Eugenol memiliki kemampuan sebagai agen larvasida alami, yang bekerja dengan cara mempengaruhi sistem saraf pada serangga ( Taher \& Paputungan, 2015; Sari et al., 2015) sedangkan kandungan saponin, flavonoid dan tanin dalam ekstrak daun 
cengkeh yang berperan sebagai larvasida terhadap larva Ae. aegypti melalui mekanisme merusak membran sel atau menggaggu proses metabolesme larva dan sebagai racun perut. Flavonoid masuk ke dalam tubuh serangga melalui sistem pernapasannya kemudian menimbulkan kerusakan pada sistem pernapasan sehingga menyebabkan terjadinya mortalitas.

\section{Waktu Kematian}

Tabel 2. Paruh Waktu $\left(\mathrm{LT}_{50}\right)$ larva Ae. aegypti dengan perlakuan ekstrak Serai Wangi dengan Daun Cengkeh dan Kombinasinya

\begin{tabular}{lccc}
\hline Perlakuan & $\begin{array}{c}\text { Nilai } \\
\text { LT }_{50} \\
(\text { Jam) }\end{array}$ & $\begin{array}{c}\text { Limit } \\
\text { Atas } \\
\text { (Jam) }\end{array}$ & $\begin{array}{c}\text { Limit } \\
\text { Bawah } \\
\text { (Jam) }\end{array}$ \\
\hline Serai Wangi & 12,72 & 14,26 & 8,24 \\
Daun & 6,71 & 8.64 & 5,76 \\
Cengkeh & 6,38 & 8,01 & 4,26 \\
Kombinasi & & &
\end{tabular}

Analisis probit menunjukkan bahwa $\mathrm{LT}_{50}$ untuk perlakuan Serai Wangi pada 12,7 jam dan Daun Cengkeh pada 6,71 jam serta kombinasinya pada 6,38 jam. Hal ini menunjukkan $50 \%$ kematian larva Ae. aegypti yang disebabkan oleh Kombinasi Serai wangi dan Daun cengkeh lebih cepat dibandingkan dengan Serai wangi. Kedua ekstrak ini kemungkinan memerlukan waktu yang berbeda untuk mematikan serangga.

Potensi toksisitas dari minyak atsiri terhadap larva Ae. aegypti sangat bervariasi sesuai dengan faktor intrinsik seperti spesies tanaman, bagian tanaman, umur tanaman dan faktor ekstrinsik yaitu kondisi geografis tempat tanaman tumbuh (seperti musim, curah hujan, persentase kelembaban, suhu, sinar matahari dan ketinggian), sumber larva dan metode yang digunakan. Oleh karena itu, antara satu tanaman dengan tanaman lainnya akan menunjukkan aktivitasnya yang berbeda walaupun berasal dari satu family (Boesri et al., 2015; Kardian \& Dhalimi, 2010; Marim \& Sitorus, 2019). Biolarvasida yang diperoleh dari jenis tanaman yang berbeda akan memperlihatkan aktivitasnya yang berbeda. Dominasi kandungan minyak atsiri antara satu famili dengan famili lainnya akan berbeda sehingga menghasilkan daya bunuh larva nyamuk berbeda pula Perbedaan tersebut terjadi karena adanya variasi kimia yang merespon terhadap perbedaan faktor luar di habitatnya.

\section{KESIMPULAN}

Konsentrasi bahan uji tidak memberikan perbedaan pengaruh yang signifikan sebagai biolarvasida. Hal ini menunjukkan bahwa Minyak Atsiri Serai Wangi dan Daun Cengkeh baik diaplikasi secara tunggal maupun dikombinasi memiliki efektifitas larvasida yang sama dengan Temephos dalam membunuh larva nyamuk Ae. aegypti. Waktu kematian $\left(\mathrm{LT}_{50}\right)$ ekstrak Serai Wangi 12,72 jam, Daun cengkeh 6,71 jam dan kombinasi 6,38 jam.

\section{UCAPAN TERIMA KASIH}

Ucapan terima kasih disampaikan kepada Rektor Universitas Sam Ratulangi dan Ketua Lembaga Penelitian dan Pengabdian Masyarakat Unsrat yang telah mendanai kegiatan penelitian ini.

\section{DAFTAR PUSTAKA}

Adiyasa, I.W.S, Santi, S.R \& Manurung, M. 2014 . Uji Aktivitas Repelen Minyak Atsiri Buah Liligundi (Vitex trifolia Linn.) terhadap Nyamuk Ae. aegypti. J.KIM., 8(1):23-27.

Adrianus, K., Suryani, A., Santos, K. \& Meika, S. 2015. The Effect of Gelling Agent Concentration on The Caracteristic of Gel Produced from the Mixture of Semi-Refined Carrageenan and Glukomannan. International Journal of Science:Basic and Applied Research. (IJSBAR), 20(1):313-324.

Ahmad, H. \& Ulfiani, E. 2018. Efektivitas Bubuk Daun Jeruk Purut (Citrus hysdrix) dan Daun Salam (Zyzygium polyanthum) sebagai Zat Penolak Alami Kecoa (Periplaneta Americana). Jurnal Sulolipu, 18(2):113-121.

Amban, Y. \& Suena, N.I. 2010. Uji Stabilitas Fisik Formulasi Lotion Anti NyamukMinyak Sereh. Jurnal Ilmiah Medicamento, 5(20):111-115.

Astriani, Y. \& Widawati, M. 2016. Potensi Tanaman di Indonesia sebagai Larvasida Alami untuk Ae. aegypti. SPIRAKEL, 8(2): 37-46. 
Boesri, H., Heriyanto, B., Susanti L \& Handayani, S.W. 2015. Uji Repelen (Daya Tolak) Beberapa Ekstrak Tumbuhan Terhadap Gigitan Nyamuk Ae. aegypti Vektor Demam Berdarah Dengue. Vektora, 7(2):79-84.

Cania, E. \& Setyaningrum, E. 2013. Uji Efektivitas Larvasida Ekstrak Daun Legundi (Vitextrifolia) terhadap Larva Ae. Aegypti. Medical Journal of Lampung University, 2(4): 52-60.

Dominica, D. \& Handayani, D. 2019. Formulasi dan Evaluasi Sediaan Lotion dari Ekstrak Daun Lengkeng (Democarpus longan) sebagai Antioksidan. Jurnal Farmasi dan Ilmu Kefarmasian Indonesia, 6(1): 1-7.

Fadillah, A.L.N., Cahyati, W.H. \& Widiaswara, R. 2017. Uji Daya Proteksi Ekstrak Daun Papaya dalam Sediaan Lotion dengan Basis PEG400 sebagai Reppelent terhadap Ae,aegypti. Jurnal Care, 1(3):318-328.

Fayemimo, K.A., Adeleke, M.A., Okoro, O.P., Awojide, S.H., Olufemi, L., \& Awoniyi. 2014. Larvacidal Efficacies and Chemical Composition of Essensial oils of Pinus sylvestris and Syzygium aromaticum Againts mosquitoes. Asian Pasific Journal of Tropical Biomedicine, 4(1): 30-34.

Gunawan, C.N. 2009. Perbandingan Ekstrak Batang Sereh (Cymbopogon citratus) dan Citronella Oil sebagai Repelen terhadap Nyamuk Culex Dewasa Betina. Jurnal Keshatan Masyarakat, 8(2).

Gutierrez. 2013. Essential Oil Used in Aromatherapy A Systemic Review. Asian Pasifik Journal of Tropical Biomedixine, 5(8): 601-611.

Herman, J. 2010. Minyak Atsiri dari Beberapa Tanaman. Jurnal Kedokteran dan Kesehatan, 6(1): 1-8.

Irianto, K. 2014. Epidemiologi Penyakit Menular dan Tidak Menular Panduan Klinis. ALFABETA, Bandung. pp:148157.

Ishak, N.I. 2019. Efektivitas Ekstrak Kulit Buah Limau kuit (Citrus amblycarpa) sebagai Larvasida Ae. aegypti Instar III. Jurnal MKMI, 15(3):302-310.
Ismuyanto, B., Agustina, D., Cakra, W.O., Saptati, D. \& Poerwadi, B. 2013. Karakteristik Gel Pengharum Ruangan dengan Berbagai Grade Patchouli Alcohol dan Konsentrasi Minyak Nilam. Jurnal Teknik Kimia, 7(2):4853.

Kardian, A. \& Dhalimi, A. 2010. Potensi Adas (Feniculum vulgare) sebagai Bahan Aktif Lotion Anti Nyamuk Demam Berdarah (Ae. aegypti. Bul. LITTRO, 21(1): 61-68.

Kihampa, C., Joseph, C.C., Nkunya, M.H.H., Magesa, S.M., Hassanali, A. \& Heydenreich, M. 2009. Larvicidal and IGR Aktivity of Extract Tanzanian Plants Againts Dengue Vector Mosquitoes. J Vektor Borne Disease, 46(2):145-152.

Kim, S.L., Yom, J.S., Baeck, S.J., Ahn, Y.I. \& Yun, H.K. 2012. Toxicity and Synergic Reppellency of Plant Essensial Oil Mixture with Vanillin Against Ae. aegypti (Dipetra: Culicidae). Journal of Medical Entomology, 49(4): 876-885.

Lukman, A., Susanti, E. \& Oktaviana, R. 2012. Formulasi Gel Minyak Kayu Manis (Cinnamon burmanii) sebagai Sediaan Antinyamuk. Jurnal Penelitian Farm. Indonesia, 1:24-29.

Maia, M.F. \& Moore, S.J. 2011. Plant Bast Insect Repellents a Review of their Efficacy Development and Testing. Malaria Journal, (Supp 1)10:1-14.

Marim \& Sitorus, H. 2019. Beberapa Tanaman yang Berpotensi sebagai Repelen di Indonesia. SPIRAKEL, 11(1): 24-33.

Nerio, L.S., Verbel, O. \& Stashenko, E. 2010. Repellent Activity of Essential Oils: A Review. Bioresource Technology, 101:372-378.

Nindatu, M., Tuhumury, N.L. \& Kaihena, M. 2011. Pengembangan Ekstrak Etanol Daun Lavender (Lavandula angustifiola) sebagai Anti Nyamuk Vektor Filariasis Culex sp. Jurnal Kedokteran dan Kesehatan, 4(1):1927.

Nugroho, A.D. 2011. Kematian Larva Ae. aegypti setelah Pemberian Serbuk Serai. Jurnal Kesehatan Masyarakat. 7(1): 91-96. 
Prasetyowati, H., Astuti, E.P. \& Ruliansyah, A. 2016. Penggunaan Insektisida Rumah Tangga dalam Pengendalian Populasi Ae. aegypti di Daerah Endemis Demam Berdarah Dengue (DBD) di Jakarta Timur. Aspirator, 8(1): 29-36.

Sari, L., Budiyono, R. \& Hestiningsih, R. 2015. Daya Tolak Repellent Bentuk Lotion dengan Ekstrak Bunga Kecombrang (Nicolaia speciose Horan) terhadap Nyamuk Ae. aegypti. Jurnal Kesehatan Masyarakat, 3(3): 754-763.

Susanti, L. \& Boesri, H. 2012. Toksisitas Biolarvasida Ekstrak Tembakau dibandingkan dengan Ekstrak Zodia terhadap Jentik Vektor Demam Berdarah Dengue. Bulletin Penelitian Kesehatan, 40(2): 75-84.

Taher, D.M. \& Papuangan, N. 2015. Potensi Cengkeh (Syzygium aromaticum) Varietas Avo Biolarvasida Alami nyamuk Anopheles subpictus dan Ae. aegypti. Prosiding Seminar Nasional Masyarakat Biodiversitas Indonesia, 6(1):1478-1482.
Utomo, P.P \& Nana, S. 2016. Perbandingan Daya Proteksi Lotion Anti Nyamuk dari Beberapa Jenis Minyak Atsiri Tanaman Pengusir Nyamuk. BEROPAL INDUSTRI, 5(2): 79-87.

Wulandari, E., Hapsari, I. \& Hartanti, D. 2011. Daya Repelan Gel Minyak Atsiri Bunga Kenanga (Kananga Odorata) (Link) daam Basis CM C Na terhadap Nyamuk Aedesaegypti. Jurnal Pharmacy, 8(1): 102-115.

Yulvianti, M., Sari, M. \& Rojalul. 2014. Pengaruh Perbandingan Campuran Pelarut N-Heksana-Etanol Terhadap Kandungan Sitronellal Hasil Ekstraksi Serai Wangi (Cymbopogon nardus). Jurnal Integrasi Proses, 5(1):8-14.

Zen, S. \& Non, R. 2016. Inventarisasi Tanaman yang Berpotensi Sebagai Bioinsektisida Nyamuk Ae. aegypti di Kota Metro Propinsi Lampng. Bioedukasi Journal Pendidik Biol, 7(2):139-143. 